\title{
PERBEDAAN HASIL PEMERIKSAAN HEMOGLOBIN DENGAN POINT OF CARE TESTING (POCT) PADA SAMPEL DARAH VENA DAN KAPILER
}

\section{Differences in Hemoglobin Test Results with Point Of Care Testing (POCT) in Blood Samples Veins and Capillaries}

\section{Reza Widianto ${ }^{\text {** }}$ \\ Dwi Purbayanti \\ Rinny Ardina ${ }^{3}$}

*IProgram Studi Analis Kesehatan, Universitas Muhammadiyah Palangkaraya, Palangkaraya, Indonesia

2Program Studi Analis Kesehatan, Universitas Muhammadiyah Palangkaraya, Palangkaraya, Indonesia

3Program Studi Analis Kesehatan, Universitas Muhammadiyah Palangkaraya, Palangkaraya, Indonesia

*email: rezawidianto.1974@gmail.com

\section{Kata Kunci:}

Kadar Hemoglobin, Darah Vena,

Darah Kapiler, POCT.

\section{Keywords:}

Hemoglobin Levels, Venous Blood, Capillary Blood, POCT.

\begin{abstract}
Abstrak
Pada pemeriksaan hemoglobin dengan POCT umumnya menggunakan darah kapiler. Penggunaan darah kapiler sebagai sampel pemeriksaan memiliki kekurangan, yaitu besarnya kemungkinan terjadinya pengenceran pada sampel darah kapiler yang disebabkan oleh tusukan yang kurang dalam sehingga darah yang keluar tidak lancar dan biasanya jari akan ditekan atau diurut. Keadaan ini dapat menyebabkan pengenceran darah oleh cairan jaringan, sehingga hasil pemeriksaan akan cenderung rendah. Tujuan dari penelitian ini adalah untuk mengetahui perbedaan hasil hemoglobin dengan POCT pada sampel darah vena dan kapiler. Penelitian ini menggunakan metode deskriptif analitik yang bertujuan untuk menggambarkan atau mendeskripsikan tentang suatu keadaan secara objektif, kemudian diuraikan. Hasil menunjukkan rerata kadar hemoglobin pada sampel darah vena adalah $13,2 \mathrm{~g} / \mathrm{dl}$. Sedangkan pada sampel darah kapiler 12,9 g/dl. Hasil uji t independent didapatkan nilai signifikansi sebesar 0,224 $(p>0,05)$ Sehingga dapat disimpulkan bahwa tidak terdapat perbedaan yang signifikan antara hasil pemeriksaan kadar hemoglobin menggunakan sampel darah vena dan sampel darah kapiler.
\end{abstract}

\begin{abstract}
On examination of hemoglobin with POCT generally use capillary blood. The use of capillary blood as a test sample has a deficiency, namely the possibility of dilution in capillary blood samples caused by a deep puncture so that the blood that comes out is not smooth and usually the fingers will be pressed or sequenced. This condition can cause blood dilution by tissue fluid, so the test results will tend to be low. The purpose of this study was to find out the difference in hemoglobin results with POCT in venous and capillary blood samples. This study uses descriptive analytical methods that aim to describe or describe a situation objectively, and then describe it. The results showed the average hemoglobin level in the venous blood sample was $13.2 \mathrm{~g} / \mathrm{dl}$. While in capillary blood samples $12.9 \mathrm{~g} / \mathrm{dl}$. The results of the independent $t$ test obtained a significance value of $0.224(p>0.05)$ so it can be concluded that there is no significant difference between the results of hemoglobin levels examination using venous blood samples and capillary blood samples.
\end{abstract}

\section{PENDAHULUAN}

Hemoglobin adalah suatu metaloprotein yaitu protein yang mengandung zat besi di dalam sel darah merah yang berfungsi sebagai pengangkut oksigen dari paru-paru keseluruh tubuh (Nidianti et al., 2019). Pemeriksaan hemoglobin di laboratorium dilakukan untuk mendiagnosa kemungkinan/ indikasi adanya anemia (Faatih, 2017). Anemia merupakan suatu keadaan dimana kadar hemoglobin dibawah nilai normal. Anemia dapat juga diartikan suatu kondisi ketika terdapat defisiensi ukuran atau jumlah eritrosit (Rosidah \& Rahmawati, 2016).

Metode sianmethemoglobin merupakan metode yang dianjurkan oleh International Committee for Standardization in Haematology (ICSH) sebagai gold standard pemeriksaan hemoglobin. Kelebihan dari 
metode ini adalah selain mudah dilakukan juga mempunyai standar yang stabil dan hampir semua hemoglobin dapat terukur kecuali sulf-hemoglobin (Faatih, 2017). Metode sianmethemoglobin telah dimodifikasi ke metode otomatis menggunakan hematology analyzer dimana keuntungannya adalah menggunakan reagen yang non toksik tidak mengandung sianida, kemudian mampu mengukur semua turunan hemoglobin seperti oksihemoglobin, methemoglobin, dan karboksihemoglobin tetapi tidak mengukur sulfohemoglobin (ICSH, 1996).

Pemeriksaan hemoglobin pada sarana pelayanan kesehatan seperti laboratorium di Rumah Sakit sebagian besar menggunakan alat hematology analyzer, akan tetapi di laboratorium puskesmas umumnya menggunakan fotometer dan metode Sahli. Pada sarana pelayanan kesehatan yang lebih rendah seperti puskesmas pembantu atau polindes lebih banyak menggunakan metode point of care testing (POCT) menggunakan alat hemoglobinometer portable (Puspitasari et al., 2020).

Pemeriksaan hemoglobin darah pada suatu kegiatan penyaringan, pengukurannya dapat menggunakan alat POCT. Alat POCT ini memiliki desain yang cocok jika digunakan untuk daerah yang jauh dari pusat pemeriksaan laboratorium, di fasilitas laboratorium tanpa pemeriksaan sel darah, di fasilitas donor darah dan di tempat praktek dokter umum. Beberapa pertimbangan penggunaan POCT adalah: jauhnya jarak pusat pemeriksaan laboratorium setempat, tindakan cepat yang dapat segera diambil terhadap pasien setelah hasil diketahui, mengurangi waktu tunggu hasil pemeriksaan laboratorium, mengurangi tingkat kesalahan yang terjadi pada saat pra analitik dan post analitik, serta meningkatkan efisiensi dan efektifitas hasil pemeriksaan (Faatih, 20l7).

Pada pemeriksaan hemoglobin dengan POCT umumnya menggunakan darah kapiler. Digunakannya darah kapiler karena sampel yang diperiksa hanya sedikit. Penggunaan darah kapiler sebagai sampel pemeriksaan memiliki kekurangan, yaitu besarnya kemungkinan terjadinya pengenceran pada sampel darah kapiler yang disebabkan oleh tusukan yang kurang dalam sehingga darah yang keluar tidak lancar dan biasanya jari akan ditekan atau diurut. Keadaan ini dapat menyebabkan pengenceran darah oleh cairan jaringan, sehingga hasil pemeriksaan akan cenderung rendah atau menurun (Khasanah, 2016).

Penelitian yang dilakukan oleh Rosidah \& Rahmawati (2016) mengenai perbedaan kadar hemoglobin metode Sahli pada darah vena dan kapiler. Berdasarkan analisa data hasil uji statistik didapatkan nilai rerata kadar hemoglobin dengan sampel darah vena adalah 15,29 g/dl, sedangkan nilai rerata kadar hemoglobin pada sampel darah kapiler adalah I3,25 g/dl, selisih rerata kadar hemoglobin darah vena dan darah kapiler sebesar 2,04 g/dl. Berdasarkan uji Independentsample t-test, hasil menyatakan terdapat perbedaan yang signifikan antara kadar hemoglobin metode Sahli pada sampel darah vena dan kapiler.

Dari penelitian yang pernah dilakukan sebelumnya masih belum ada penelitian yang mengukur kadar hemoglobin dengan metode POCT menggunakan sampel darah vena dan kapiler. Oleh sebab itu peneliti tertarik untuk meneliti perbedaan hasil pemeriksaan hemoglobin dengan POCT pada sampel darah vena dan kapiler.

\section{METODE PENELITIAN}

Penelitian ini menggunakan metode deskriptif analitik. penelitian dilaksanakan dari bulan Januari - Juni 2021 dilakukan di Laboratorium Instrumentasi Universitas Muhammadiyah Palangkaraya. Populasi adalah Mahasiswi Fakultas IImu Kesehatan Universitas Muhammadiyah Palangkaraya. Jumlah sampel 16 orang Mahasiswi Fakultas IImu Kesehatan Universitas Muhammadiyah Palangkaraya.

Teknik pengambilan sampel menggunakan metode purposive sampling dengan kriteria sampel yaitu: berjenis kelamin perempuan, tidak sedang menstruasi, tidak merokok, tidak mengkonsumsi alkohol, tidak 
Widianto, Purbayanti, Ardina. 2021. Differences in Hemoglobin Test Results with Point Of Care Testing (POCT) in Blood Samples Veins and Capillaries

mengkonsumsi obat penambah darah, dalam keadaan sehat (tidak memiliki riwayat thalasemia, leukimia, anemia).

Analisis data dilakukan dengan menggunakan uji independent $t$ test, untuk mengetahui ada tidaknya perbedaan hasil pemeriksaan kadar hemoglobin dengan POCT pada sampel darah vena dengan sampel darah kapiler.

\section{HASIL DAN PEMBAHASAN}

HASIL

Tabel I. Hasil Kadar Hemoglobin dengan POCT Sampel N Rerata Nilai maks Nilai min

\begin{tabular}{rrrrr}
\hline Vena & 16 & 13.2 & 14.3 & 12.1 \\
\hline Kapiler & 16 & 12.9 & 14.2 & 12.0 \\
\hline
\end{tabular}

Berdasarkan Tabel I di atas, kadar $\mathrm{Hb}$ yang diperiksa pada sampel darah vena dari 16 sampel didapatkan rerata kadar $\mathrm{Hb}$ sebesar 13,2 g/dl, sedangkan 16 sampel yang diperiksa pada darah kapiler didapatkan rerata kadar $\mathrm{Hb}$ sebesar $12,9 \mathrm{~g} / \mathrm{dl}$, dimana rerata hasil pemeriksaan $\mathrm{Hb}$ menggunakan sampel darah vena lebih tinggi dibandingkan dengan sampel darah kapiler, dengan selisih $0,3 \mathrm{~g} / \mathrm{dl}$. Pada sampel darah vena didapatkan hasil Hb maksimum sebesar 14,3 g/dl dan untuk minimumnya sebesar 12,I g/dl. Sedangkan sampel darah kapiler didapatkan hasil Hb maksimum sebesar 14,2 g/dl dan untuk minimumnya sebesar $12,0 \mathrm{~g} / \mathrm{dl}$.

Tabel II. Uji Normalitas, Homogenitas dan Independent T-Test

\begin{tabular}{|c|c|c|c|}
\hline No & Jenis Uji & $\begin{array}{c}\text { Nilai } \\
\text { Signifikansi }\end{array}$ & Hasil \\
\hline \multirow[t]{3}{*}{ I. } & $\begin{array}{l}\text { Normalitas } \\
\text { (Shapiro wilk) }\end{array}$ & & \\
\hline & - Vena & 0,094 & Normal \\
\hline & - Kapiler & 0,521 & Normal \\
\hline 2. & Homogenitas & 0,137 & Homogen \\
\hline 3. & $\begin{array}{l}\text { Uji beda "T- } \\
\text { test" }\end{array}$ & 0,224 & $\begin{array}{c}\text { Tidak } \\
\text { terdapat } \\
\text { perbedaan } \\
\text { yang } \\
\text { signifikan. }\end{array}$ \\
\hline
\end{tabular}

Pada Tabel II di atas didapatkan hasil pemeriksaan hemoglobin pada sampel darah vena dan sampel darah kapiler berdistribusi normal. Hal tersebut ditunjukkan nilai signifikansi kadar hemoglobin pada sampel darah vena 0,094 , sedangkan nilai signifikansi kadar hemoglobin pada sampel darah kapiler 0,521. Kesimpulan dasar pengambilan keputusan jika nilai signifikansi $>0,05$, maka data berdistribusi normal. Dari tabel di atas diketahui bahwa hasil pemeriksaan hemoglobin pada sampel darah vena dan kapiler dinyatakan homogen. Didapatkan nilai signifikansi sebesar 0, I 37 dengan dasar pengambilan keputusan jika nilai signifikansi $>0,05$, maka distribusi data adalah homogen.

Perbedaan antara hasil pemeriksaan $\mathrm{Hb}$ pada sampel darah vena dan kapiler dianalisis secara statistik menggunakan uji independent sample $t$ test. Hasil analisis menunjukkan bahwa tidak terdapat perbedaan yang signifikan secara statistik antara rerata hasil pemeriksaan $\mathrm{Hb}$ pada sampel darah vena dan kapiler dengan alat POCT. Hal ini ditunjukkan dengan nilai sig (2-tailed) sebesar 0,224>0,05 yang berarti $\mathrm{H} 0$ diterima dan Ha ditolak.

\section{PEMBAHASAN}

Hasil penelitian ini sejalan dengan penelitian yang dilakukan oleh Rosidah \& Rahmawati (2016) yang menyatakan bahwa kadar $\mathrm{Hb}$ pada darah vena lebih tinggi daripada kadar $\mathrm{Hb}$ darah kapiler menggunakan metode Sahli. Menurut Prasetya et al. (2016) menyatakan bahwa pada saat pengambilan darah kapiler, jari yang diambil darahnya diperlakukan dengan cara dipijat hingga darahnya keluar, pemijatan tersebut menyebabkan cairan yang ada di dalam jaringan ikut keluar bersama dengan darah sehingga menyebabkan darah kapiler menjadi lebih encer. Berbeda dengan ukuran pembuluh darah vena yang berukuran besar. Namun penelitian ini tidak sejalan dengan penelitian Puspitasari et al. (2020) yang menyatakan bahwa kadar $\mathrm{Hb}$ pada darah kapiler metode POCT lebih tinggi 
dibandingkan dengan kadar $\mathrm{Hb}$ pada darah vena metode Sianmethemoglobin. Selain itu penelitian yang dilakukan oleh Eslami et al. (2012) pada sampel neonatus didapatkan sampel kapiler memiliki konsentrasi hemoglobin rata-rata yang lebih tinggi daripada sampel vena. Hal tersebut dikarenakan eritrosit pada neonatus mengalir lambat melalui kapiler, sehingga yang terjadi adalah eritrosit akan banyak terkonsentrasi di kapiler, sehingga menyebabkan kadar hemoglobin pada sampel kapiler lebih tinggi daripada kadar hemoglobin sampel vena.

Carlson et al. (2008) menyatakan bahwa kadar hemoglobin kapiler lebih tinggi dibandingkan dengan kadar hemoglobin pada darah vena, karena oksigen dalam darah vena merupakan sisa oksigen dari hasil pertukaran oksigen yang terjadi di kapiler. Namun perlu diingat pada saat proses pengambilan sampel darah kapiler tidak selalu terambil secara representatif terkadang dalam proses pengambilan sampel darah kapiler masih perlu dilakukan pemijatan sehingga hal tersebut dapat menyebabkan hemodilusi dan menghasilkan kadar hemogolobin pada sampel darah kapiler lebih rendah dari kadar hemoglobin sampel darah vena.

Penelitian ini sejalan dengan yang dilakukan oleh Puspitasari et al. (2020) menyatakan tidak ada perbedaan yang signifikan antara kadar $\mathrm{Hb}$ pada darah vena metode Sianmethemoglobin dengan kadar $\mathrm{Hb}$ pada darah kapiler metode POCT. Namun penelitian ini tidak sejalan dengan penelitian yang dilakukan oleh Rosidah \& Rahmawati (2016) yang menyatakan terdapat perbedaan yang signifikan antara kadar $\mathrm{Hb}$ pada sampel darah vena dan darah kapiler metode Sahli.

Pada dasarnya darah vena dan darah kapiler sama, berada dalam satu siklus peredaran darah yang saling berkaitan dan keduanya dapat digunakan sebagai sampel untuk pemeriksaan hematologi khususnya pemeriksaan kadar hemoglobin (Rosidah \& Rahmawati, 20/6). Dengan demikian menyebabkan hasil analisis secara statistik antara rata-rata hasil pemeriksaan hemoglobin pada sampel darah vena dan kapiler tidak menunjukkan perbedaan yang signifikan sehingga sampel darah vena maupun darah kapiler dapat digunakan untuk pemeriksaan hemoglobin menggunakan POCT.

\section{KESIMPULAN}

Pada penelitian kali ini dilakukan uji $t$ independent untuk mengetahui adanya perbedaan. Didapatkan nilai signifikansi sebesar 0,224 ( $p>0,05)$, Sehingga dapat disimpulkan bahwa tidak terdapat perbedaan yang signifikan antara hasil pemeriksaan kadar $\mathrm{Hb}$ menggunakan sampel darah vena dan sampel darah kapiler. Saran untuk peneliti selanjutnya yaitu membandingan hasil kadar $\mathrm{Hb}$ pada sampel darah vena dan kapiler pada sampel patologis.

\section{DAFTAR PUSTAKA}

Carlson, B. E., Anderson, J. C., Raymond, G. M., Dash, R. K., Bassingthwaighte, J. B. 2008. Modeling Oxygen and Carbon Dioxide Transport and Exchange Using a Closed Loop Circulatory System. Advances in Experimental Medicine and Biology. 6I4, pP 353-360. DOI: 10.1007/9780-387-749। I-2.

Eslami, Z., Ghilian, R., Abassi, F. 2012. Evaluation of Hemoglobin Concentration of Cord, Capillary and Venous sampling in Neonates. Iranian Journal of Pediatric Hematologi Oncology, 2 (4), PP I59-163.

Faatih, M. 2017. Penggunaan Alat Pengukur Hemoglobin di Puskesmas, Polindes dan Pustu. Jurnal Penelitian dan Pengembangan Pelayanan Kesehatan, I (I) : 32-39.

ICSH. 1996. Recommendations for haemoglobinometry in human blood (ICSH standard 1995) and specifications for international haemoglobincyanide standard. $4^{\text {th }}$ editions. J Clin Path. 49: 74-27I.

Khasanah, Uswatun. 2016. Perbedaan hasil pemeriksaan hitung jumlah trombosit pada darah vena dan darah kapiler dengan metode tabung. Skripsi. Universitas Muhammadiyah Semarang, Semarang.

Nidianti, E., Nugraha, G., Aulia, I. A. N., Syadzila, S. K., Suciati, S. S., \& Utami, N. D. 2019. Pemeriksaan Kadar Hemoglobin dengan 
Widianto, Purbayanti, Ardina. 2021. Differences in Hemoglobin Test Results with Point Of Care Testing (POCT) in Blood Samples Veins and Capillaries

Metode POCT (Point of Care Testing) sebagai Deteksi Dini Penyakit Anemia Bagi Masyarakat Desa Sumbersono, Mojokerto. Jurnal Surya Masyarakat, 2(I) : 29-34.

Prasetya, H. R., Dentri, M. I., Sistiyono. 2016. Perbedaan Hitung Jumlah Trombosit Menggunakan Darah Vena dan Darah Kapiler. Journal Of Health 3(2). 62-II7

Puspitasari., Aliviameita, A., Rinata, E., Yasmin, R. A. Y., \& Saidah, S. N. 2020. Perbedaan Hasil Pemeriksaan Hemoglobin Antara Metode Point of Care Testing Dengan Metode Sianmethemoglobin Pada Ibu Hamil. Jurnal Analis Kesehatan, 9(I) : 24.

Rosidah, \& Rahmawati, N. K. 2016. Perbedaan Kadar Hemoglobin Metode Sahli pada Darah Vena dan Kapiler di Puskesmas Tikung Desa Bakalan Pule Kec.Tikung Kab.Lamongan. Jurnal Sains, 6(II) : 2I-26. 